\title{
REHABILITATION THERAPY WITH INSULIN-LIKE GROWTH FACTOR AFTER ACUTE SKELETAL MUSCLE INJURY
}

\author{
TERAPIA DE REABILITAÇÃO COM FATOR DE CRESCIMENTO SEMELHANTE À INSULINA APÓS LESÃO \\ MUSCULARESQUELÉTICA AGUDA
}

\author{
TERAPIA DE REHABILITACIÓN CON FACTOR DE CRECIMIENTO SEMEJANTE A LA INSULINA DESPUÉS \\ DE UNA LESIÓN AGUDA DEL MÚSCULO ESQUELÉTICO
}

\section{Qing Wang' (iD) \\ (Physical Education Professional) Fen Wang ${ }^{2}$ (ID \\ (Physical Education Professional)}

1. Jiangxi Teachers College, Jiangxi, Yingtan, China.

2. Yifu Primary School of Yingtan, Jiangxi, Yingtan, China.

\section{Correspondence:}

Qing Wang, Jiangxi Teachers

College, Jiangxi, Yingtan, 335000,

China.huwei840213@163.com

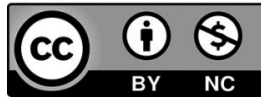

\begin{abstract}
Introduction: Skeletal muscle injuries account for 10\% to 50\% of treadmill sports injuries. Insulin-like growth factor (IGF) is a family of polypeptides with both insulin-like anabolic and growth-promoting effects. Sports play a vital role in the recovery of skeletal muscle injuries. Objective: The paper analyzes the ability of insulinlike growth factor 1 (IGF-1) to repair skeletal muscle injury caused by treadmill exercise. Method: We injected drugs under the wound after exercise-induced injury in rats. The control group was injected with saline, and the experimental group was injected with an insulin-like growth factor. We conduct histological and electron microscopic structural analysis of rats, Results: After an injury, the experimental group formed a basal lamina protective film earlier than the control group, activated myoblasts, formed myofilaments, formed myotubes, and fused into muscle fibers earlier than the control group. The healing quality was also better. The experimental group was endogenous. The mRNA content of sex IGF-1 and IGF-2 both increased earlier than the control group. Conclusion: Local injection of exogenous insulin-like growth factor-1 can stimulate the proliferation of myoblasts and accelerate the post-traumatic repair process of skeletal muscle caused by treadmill sports. Level of evidence Il; Therapeutic studies - investigation of treatment results.
\end{abstract}

Keywords: Treadmill sports; insulin-like growth factor-1; skeletal muscle; wound repair.

\section{RESUMO}

Introdução: As lesões do músculo esquelético representam de 10\% a 50\% das lesões em esteira esportiva. O fator de crescimento semelhante à insulina (IGF) é uma família de polipeptídeos com efeitos anabólicos e de promoção do crescimento semelhantes à insulina. Os esportes desempenham um papel vital na recuperação de lesões musculares esqueléticas. Objetivo: o artigo analisa a capacidade do fator de crescimento semelhante à insulina 1 (IGF-1) em reparar lesões musculares esqueléticas causadas por exercícios em esteira. Método: Injetamos drogas sob a ferida após lesão induzida por exercício em ratos. O grupo controle foi injetado com solução salina e o grupo experimental foi injetado com um fator de crescimento semelhante à insulina. Realizamos análises histológicas e microscópicas eletrônicas estruturais de ratos. Resultados: Após a lesão, o grupo experimental formou um filme protetor da lâmina basal mais cedo do que o grupo controle, mioblastos ativados, miofilamentos formados, miotubos formados e fundidos em fibras musculares mais cedo do que o grupo controle. A qualidade da cura também foi melhor. O grupo experimental era endógeno. O conteúdo do sexo IGF-1 e IGF-2 mRNA aumentou mais cedo do que no grupo de controle. Conclusão: A injeção local de fator de crescimento semelhante à insulina 1 exógeno pode estimular a proliferação de mioblastos e acelerar o processo de reparo muscular esquelético pós-traumático causado por esportes em esteira. Nível de evidência ll; Estudos terapêuticos: investigação dos resultados do tratamento.

Descritores: Esportes na esteira; fator de crescimento semelhanteà insulina-1; músculo esquelético; reparo de feridas.

\section{RESUMEN}

Introducción: Las lesiones del músculo esquelético representan del 10\% al 50\% de las lesiones deportivas en cinta. El factor de crecimiento semejante a la insulina (IGF) es una familia de polipéptidos con efectos anabólicos y estimulantes del crecimiento semejantes a la insulina. Los deportes juegan un papel vital en la recuperación de las lesiones del músculo esquelético. Objetivo: El artículo analiza la capacidad del factor de crecimiento semejante a la insulina 1 (IGF-1) para reparar la lesión del músculo esquelético causada por el ejercicio en cinta. Método: inyectamos drogas debajo de la herida después de una lesión inducida por el ejercicio en ratas. Al grupo de control se le inyectó solución salina y al grupo experimental se le inyectó un factor de crecimiento semejante a la insulina. Realizamos análisis estructurales histológicos y microscópicos electrónicos de ratas, Resultados: Después de una lesión, el grupo experimental formó una película protectora de la lámina basal antes que el grupo de control, activó mioblastos, formó miofilamentos, formó miotubos y se fusionó en fibras musculares antes que el grupo de control. La calidad de curación también fue mejor. El grupo experimental fue endógeno. El contenido de ARNm de IGF-1 elGF-2 de sexo 
aumentaron antes que en el grupo de control. Conclusión: La inyección local de factor de crecimiento semejante a la insulina 1 exógeno puede estimular la proliferación de mioblastos y acelerar el proceso de reparación postraumático del músculo esquelético causado por los deportes en cinta. Nivel de evidencia ll; Estudios terapéuticos: investigación de los resultados del tratamiento.

Descriptores: Deportes en cinta rodante; factor de crecimiento semejante a la insulina-1; músculo esquelético; reparación de heridas.

\section{INTRODUCTION}

Skeletal muscle injuries account for $10 \%$ to $50 \%$ of sports injuries. Due to skeletal muscle regeneration's limited ability, structural and functional recovery after injury is often incomplete, accompanied by a certain degree of fibrosis. Insulin-like growth factor (IGF) is a polypeptides family that has both insulin-like anabolic and growth-promoting effects. In this paper, an experimental rat skeletal muscle treadmill sports injury model was made.' Exogenous IGF-1 was injected locally outside the injury's subcutaneous muscle membrane to observe the histological and ultrastructural changes in skeletal muscle injury repair. We detect the gene expression of local endogenous IGF-1 and IGF-2 in the process of skeletal muscle regeneration, to understand the therapeutic effect of exogenous IGF-1 and its influence on the expression of endogenous IGF, and to explore exogenous IGF -1 A possible mechanism to promote the healing of skeletal muscle treadmill sports injuries. ${ }^{2}$

\section{MATERIALS AND METHODS}

\section{Experimental rat skeletal muscle treadmill sports injury model}

Male SD rats (180-220g) were injured after treadmill exercise. The injured part was the right calf's inner surface (the subcutaneous part of the gastrocnemius muscle).

\section{Animal grouping and handling}

There are 82 male S.D. rats. The rats were divided into experimental groups and control groups. Immediately after injury, $0.1 \mathrm{ml}$ of exogenous IGF-11.5 $\mu \mathrm{g}$ (experimental group) or $0.1 \mathrm{ml}$ of normal saline (control group) was injected into the injured area's subcutaneous muscle membrane. Part of the rats (60 rats) were sacrificed on the 1, 2, 3, 4, 6, 9 and 14 days after injury, 4 rats in each group every day, a total of 28 rats in the experimental group and 28 rats in the control group. In the experiment, the right lower limb muscle (including gastrocnemius muscle) was extracted, and total RNA was extracted for reverse transcription (R.T.), polymerase chain reaction (PCR) and agarose gel electrophoresis to understand the mRNA content changes of endogenous IGF-1 and IGF-2.

\section{REVERSE TRANSCRIPTION REACTION (R.T.)}

\section{IGF-1 observation part}

In the experiment, the vacuum-dried total RNA was dissolved in $1 \mathrm{ml}$ sterile redistilled water in an ice bath, and $0.25 \mathrm{ml} 2.5 \mathrm{MKCl}$ and $41.5 \mu \mathrm{l}$ 1.5MTris-HClpH7.5 buffer were added, which is the RNA template. We take

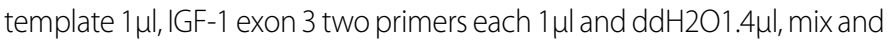
shake well; $98{ }^{\circ} \mathrm{C}$, $8 \mathrm{~min}$; ice bath, $5 \mathrm{~min}$; then add AMVRT5 $\times$ buffer $2 \mu$,

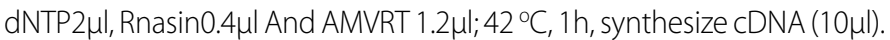

\section{IGF-2 observation part}

In the experiment, the vacuum-dried total RNA was dissolved in $1 \mathrm{ml}$ sterile redistilled water in an ice bath, and $0.25 \mathrm{ml} 2.5 \mathrm{MKCl}$ and $41.5 \mu \mathrm{l} 1.5 \mathrm{M}$ Tris-HClpH7.5 buffer were added. This is the RNA template. ${ }^{3}$ We take template $1 \mu \mathrm{l}$, IGF-2 exon 3 two primers each $1 \mu \mathrm{l}$ and ddH2O1.4 $\mu$, mix and shake uniformly; $98^{\circ} \mathrm{C}, 8 \mathrm{~min}$; ice bath, $5 \mathrm{~min}$; then add AMVRT5X buffer $2 \mu \mathrm{l}$, dNTP2 $\mu \mathrm{l}$, Raisin $0.4 \mu \mathrm{l}$ And AMVRT $1.2 \mu \mathrm{l} ; 42^{\circ} \mathrm{C}$, $1 \mathrm{~h}$; Synthesize cDNA $(10 \mu \mathrm{l})$.

\section{Statistical Algorithm}

A one-variable linear regression equation can express the changing trend of genes:

$$
y=b_{0}+b_{1} x
$$

In the formula $b_{0}, b_{1}$ is the empirical regression coefficient, which is obtained by the least square method; $x$ is the year of observation; $b_{1}$ is the slope of the regression line, which represents the trend of gene change. Generally, $10 \times b_{1}$ represents the changing trend of $10 a$, in mm/10a.

\section{Moving average analysis}

We take the average of several early and late sequence values $\left\{x_{n}\right\}$ to obtain a new sequence $\left\{y_{t}\right\}$ to smooth the original sequence. ${ }^{4}$ This is the moving average method. The mathematical expression is

$y_{t}=\frac{1}{2 k+1} \sum_{i=-k}^{k} x_{t+i}$

When $k=1$, it is a 3-point moving average. The moving average can clearly and intuitively show a particular trend of the sequence and reduce random factors.

\section{Markov Chain}

A Markov chain is a Markov process with discrete-time and state. Suppose the state space $I=\{1,2,3, \cdots\}$, the matrix composed of transition probability $P_{i j}$ as elements, are

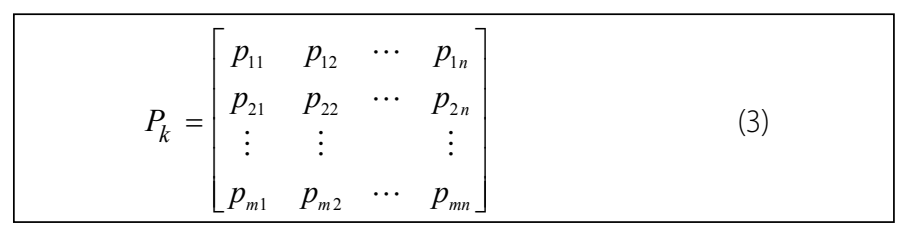

The matrix, as mentioned above, is called the k-step transition matrix. This article only considers the case of homogeneous Markov chains.

\section{RESULTS}

\section{Expression of IGF mRNA}

The mRNA content of endogenous IGF-1 and IGF-2 in the skeletal muscle of normal uninjured rats is minimal, which could not be detected by RT-PCR qualitative method (Figure 1a, b); the mRNA of IGF-1 after injury in the control group the content increased at 2, 3, 4, 6, 9, and 14 days (Figure 1a). The mRNA content of IGF-2 increased at 3, 4, 6, and 9 days (Figure $1 \mathrm{~b}$ ). The mRNA content of IGF-1 in the experimental group increased at 1, 2, 3, 4, 6, and 9 days after injury (Figure 1c), 


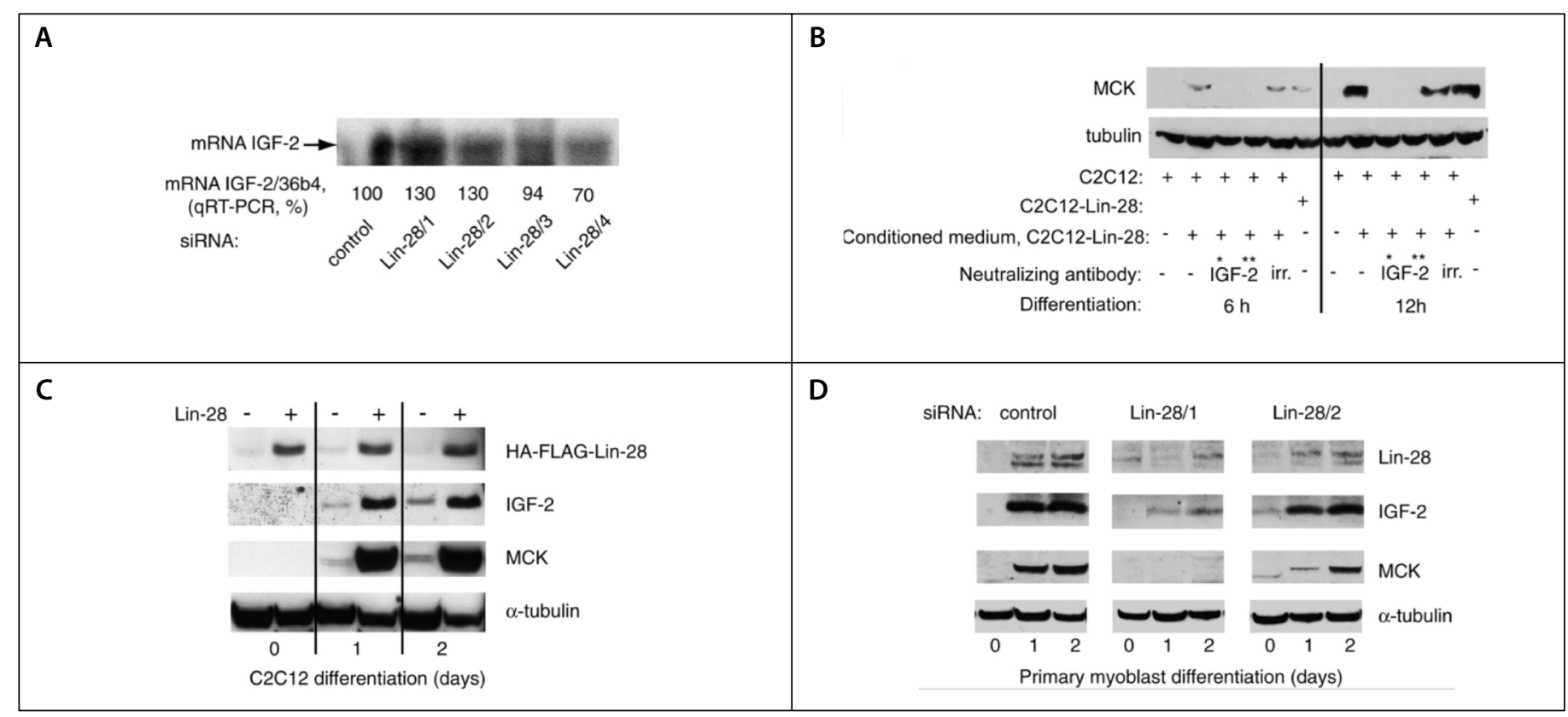

Figure 1. Expression of IGF mRNA.

and the mRNA content of IGF-2 was both at 1, 2, 3, 4, 6, 9, and 14 days. Elevated (Figure 1d).

A. The content of IGF-1 endogenously expressed in the skeletal muscle of normal uninjured rats is very low.

B. The mRNA content of IGF-2 endogenously expressed in the musculoskeletal muscle of normal uninjured rats is very small.

C. The mRNA content of endogenously expressed IGF-1 in rats treated with IGF-1 after injury increased on 1, 2, 3, 4, 6, and 9 days.

D. After injury, the mRNA content of endogenously expressed IGF-2 in rats treated with IGF-1 increased at 1, 2, 3, 4, 6, 9, and 14 days.

\section{Histological changes of the light microscope}

Immediately after the injury, the gastrocnemius muscle was locally hyperemia, edema, and degeneration, and some muscle fibers were broken. On the 1st day, the skeletal muscle fibers in the control group were disintegrated and fragmented, and inflammatory cells were infiltrated; the experimental group's inflammatory cells were concentrated in the damaged muscle fiber cells. On $4 d$ and $6 \mathrm{~d}$, a large number of myoblasts appeared in the injury of the control group, and the nuclei were arranged in a beaded shape, and myotubes were formed (Figure 2a); the experimental group had a large number of new myotubes and myofibroblasts, and the number of nuclei was vast. ${ }^{5}$ The nucleus of the tube is located in the center of the cell, and the nucleus of the muscle fiber is located at the edge of the cell (Figure 2b). On the 14th day, the myotubes in the control group were fused into muscle fibers. Some collagen fiber scars were formed; in the experimental group, regeneration was relatively complete, and there were no fibrous scars.

A: A large number of myoblasts appeared in the injury of the control group, the nuclei were arranged in a beaded shape, and myotubes were formed ( $\times 200)$. B: The experimental group has a large number of new myotubes and myofiber cells, with a vast number of nuclei. The myotube's nucleus is located in the center of the cell, and the nucleus of the muscle fiber is located at the edge of the cell $(\times 200)$.

\section{Observation of Ultrastructure by Electron Microscope}

Immediately after the injury, the gastrocnemius muscle filaments were disordered and broken (Figure 3a). On the 1st day, the myofilaments of the control group were disintegrated and fragmented, and many phagocytic fragments of inflammatory cells appeared (Figure 3b);

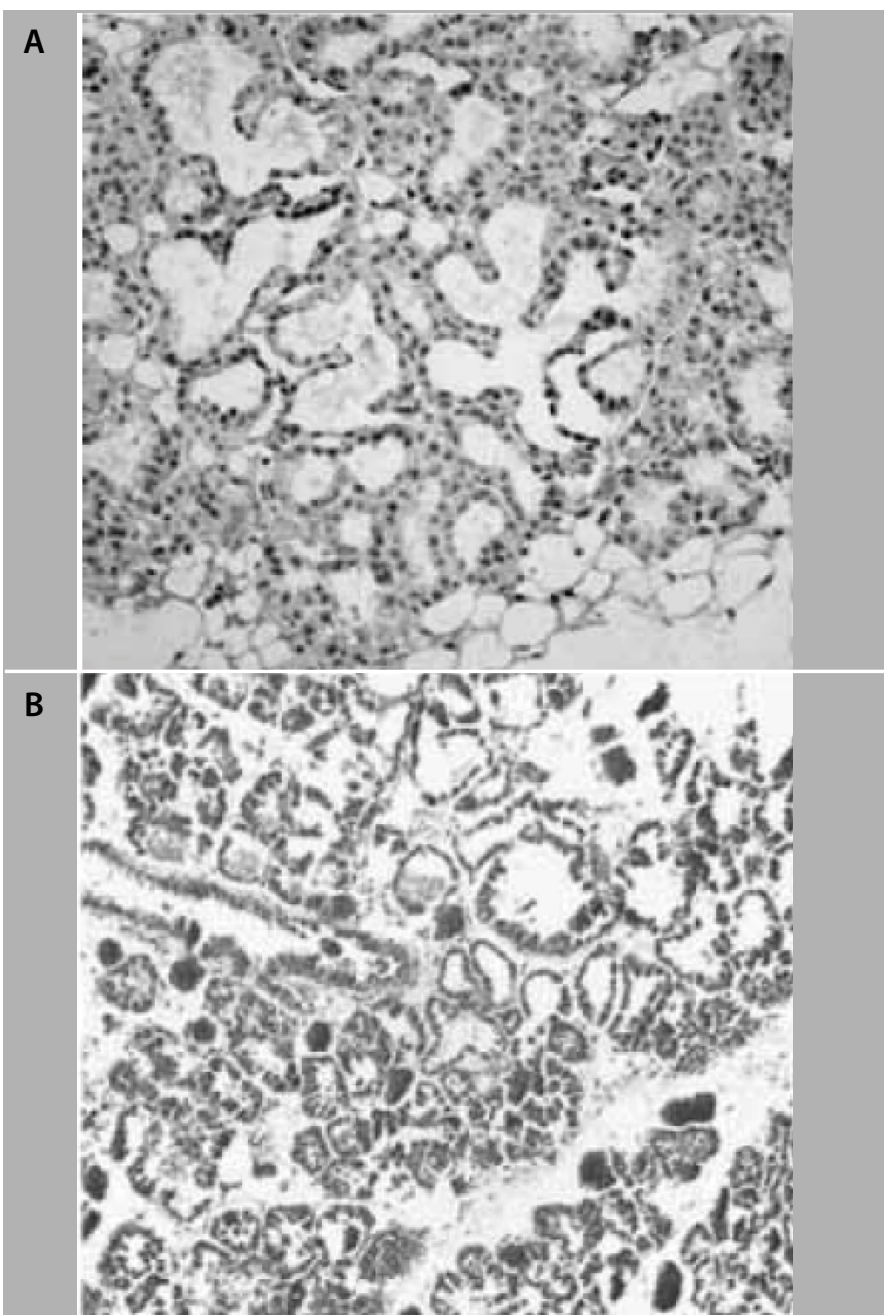

Figure 2. Optical microscopic histological changes on the 4th day after injury.

the experimental group had an apparent basal lamina protective film, and myoblast nuclei were very rich, and there were newly formed myofilaments around the nuclei (Figure $3 c, d$ ). On the 4 th and 6 th day, the control group composed of muscle cells and myotubes appeared, and many myofilaments formed around the nucleus; the experimental group myotubes merged into new muscle fibers. ${ }^{6}$ 


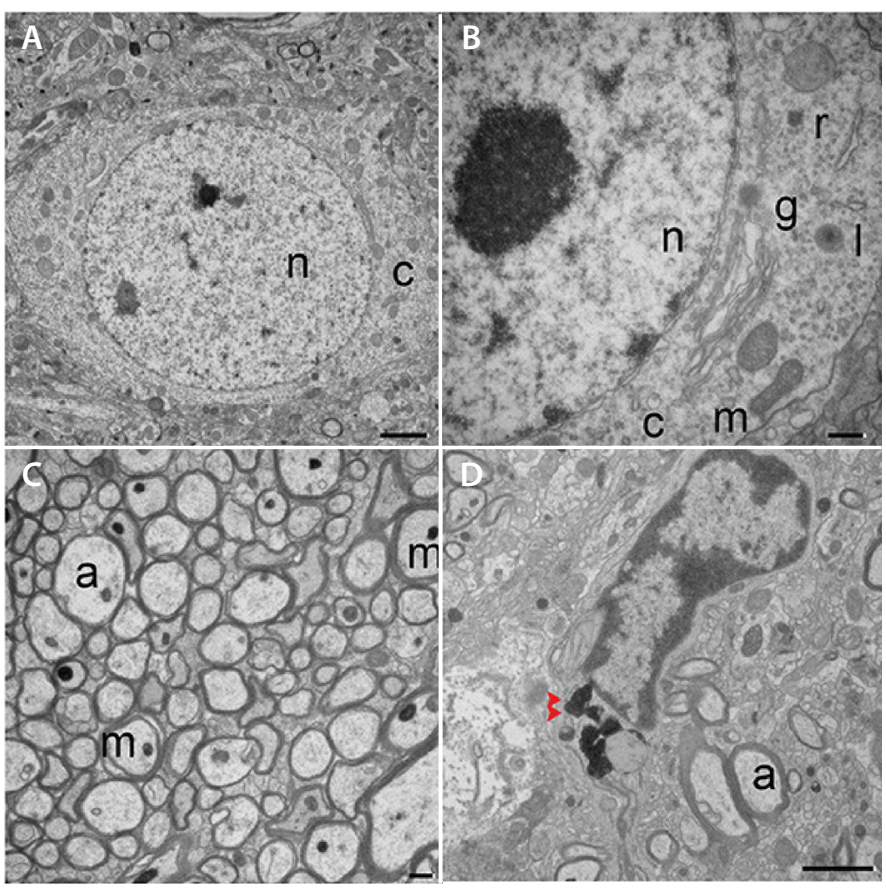

Figure 3. Ultrastructure observation of electron microscope.

A: Immediately after the injury, the gastrocnemius muscle filaments are disordered and broken (×10000). B: 1 day after the injury, myofilaments in the control group disintegrated and fragmented, and phagocytic fragments of inflammatory cells appeared $(\times 10000)$. C: 1 day after the injury, the experimental group had a transparent basal lamina protective film ( $\times 10000)$ in the damaged boundary area. D: 1 day after the injury, the myoblast nucleus in the experimental group is vibrant, and there are newly formed myofilaments (×10000) around the nucleus.

\section{DISCUSSION}

\section{The natural healing process after skeletal muscle injury}

After the skeletal muscle is traumatized, the muscle fiber membrane is damaged, intracellular $\mathrm{Ca}^{2+}$ overflows, leading to increased local $\mathrm{Ca}^{2+}$ concentration, activating $\mathrm{Ca}^{2+}$-dependent proteases, inhibiting normal mitochondrial respiration, activating complement, recruiting inflammatory cells, and causing local necrosis. Both multinucleated leukocytes and mononuclear macrophages are involved in this local phagocytic process. The natural healing observed is inflammatory cell infiltration on the 1st day after the injury, myoblasts on the 4th day, and myoblast fusion on the 6th day. Myotubes still have myotube fusion on the 14th day, and some collagen fiber scars are formed.

\section{The effect of exogenous application of IGF on the healing pro- cess of skeletal muscle and the expression of endogenous IGF}

There is endogenous IGF expression during skeletal muscle regeneration, and IGF-1 and IGF-2 are related to different stages of regeneration: in the proliferation stage, IGF-1 is significantly increased; in the differentiation stage, IGF-2 is significantly increased; proliferation first Yu differentiation. This experiment found that after skeletal muscle injury in the natural healing process, IGF-1mRNA began to rise on the 2nd day, and IGF-2mRNA began to rise on the $3 r d$ day. The research conclusion is the same.

IGF-1 is a polypeptide that binds to membrane receptors. It affects all aspects of cell growth and development through signal transduction, increasing protein synthesis in skeletal muscle and reducing protein degradation. The rate of muscle protein synthesis in rats is consistent with the change of IGF-1 mRNA content. The increase of IGF-1 polypeptide level is earlier than the increase of muscle protein content, and it is related to the increase of skeletal muscle DNA content.

\section{The possible mechanism of IGF promoting healing after skeletal muscle injury}

Some factors regulate the process of cell regeneration and proliferation. First, there is contact inhibition between cells. In the necrotic area, both myoblasts and fibroblasts may proliferate and differentiate. There is a competition mechanism between them if the exogenous IGF application can promote myoblasts' growth faster and occupy the necrotic area as soon as possible. This is the extracellular matrix component. They formed a boundary after injury to protect the undamaged area and ensure the regeneration environment. It needs to be pointed out that the expression of endogenous IGF mRNA does not represent IGF production, during which it still needs to go through the translation process. Hence, the local IGF polypeptide expression needs to be further determined in the future.

\section{Issues related to the application of IGF}

A local application can contact the wound tissue and release the growth factor slowly. Still, the effect is minimal if only the aqueous solution containing the growth factor is used locally, so the dosage form of the growth factor as a drug is fundamental. The experiment found that IGF combined with albumin can obtain satisfactory results. Since IGF affects stimulating protein synthesis and promoting cell growth, it is still unknown whether a long-term application will cause cancer or other hyperproliferative diseases.

\section{CONCLUSION}

According to people's local application experience, this time using a single injection of IGF-1, it is observed that local injection of IGF can accelerate the speed and quality of muscle wound healing. Therefore, it can be considered that the one-time use of IGF in the early post-injury period affects the repair of skeletal muscle injury. It is hoped that a new method can be found for early recovery after a sports injury, prolong sports career, and improve the quality of life, but only tentatively adopting $1.5 \mu \mathrm{g}$ Local one-time injection. What dosage is more appropriate is still a lot of experimental work to explore in the future.

All authors declare no potential conflict of interest related to this article

AUTHORS' CONTRIBUTIONS: Each author made significant individual contributions to this manuscript. Qing Wang: writing and performing surgeries; Fen Wang: data analysis and performing surgeries, article review and intellectual concept of the article.

\section{REFERENCES}

1. Gresham, R. C., Bahney, C. S., \& Leach, J. K. Growth factor delivery using extracellular matrix-mimicking substrates for musculoskeletal tissue engineering and repair. Bioactive Materials. 2021;6(7): 1945-1956

2. Zheng, L., Liu, X., Chen, P., \& Xiao, W. Expression and role of IncRNAs in the regeneration of skeletal muscle following contusion injury Corrigendum in/10.3892/etm. 2019.8271. Experimental and therapeutic medicine. 2019;18(4): 2617-2627

3. Shalaby, M., Sakoury, M. M. A., Harthi, S. M., Alshalawi, F. M., Alhajji, M. M., Alshaikh, Z. H., \& Aljaber, A. H.Vitamin D3 for Health and Muscle Functions of Athletes. Systematic Reviews in Pharmacy. 2020;1 (9): $851-854$

4. Greising, S. M., Corona, B. T., \& Call, J. A. Musculoskeletal regeneration, rehabilitation, and plasticity following traumatic injury. International journal of sports medicine. 2020;41(08): 495-504
5. Wang, X., \& Yang, L. Changes in Transcription and Translation of Transforming Growth Factor-[beta] 1 in Skeletal Muscle of Rats after Exercise Injury. Revista Científica de la Facultad de Ciencias Veterinarias. 2020;30(5): 2399-2407

6. Taniguchi, Y., Yoshioka, T., Sugaya, H., Gosho, M., Aoto, K., Kanamori, A., \& Yamazaki, M. Growth factor levels in leukocyte-poor platelet-rich plasma and correlations with donor age, gender, and platelets in the Japanese population. Journal of experimental orthopaedics. 2019;6(1): 1-8

Baria, M., Vasileff, W. K., Miller, M., Borchers, J., Flanigan, D. C., \& Durgam, S. S. Cellular components and growth factor content of platelet-rich plasma with a customizable commercial system. The American journal of sports medicine. 2019; 47(5): 1216-1222 